Dube, B. \& Ndaba, X.P. Educating Progressed Learners in Times of COVID-19: How Can Bricolage Help?

\title{
Educating Progressed Learners in Times of COVID-19: How Can Bricolage Help?
}

\author{
Bekithemba Dube ${ }^{* 1}$ and Xolisile P. Ndaba ${ }^{1}$ \\ *Corresponding Author: dubeb@ufs.ac.za \\ 1. University of the Free State, QwaQwa, South Africa \\ Received : 2021-06-06 \\ Revised : 2021-08-02 \\ Accepted : 2021-08-25 \\ dol \\ $10.46303 /$ ressat.2021.9
}

\begin{abstract}
How to cite this paper: Dube, B. \& Ndaba, X.P. (2021). Educating Progressed Learners in Times of COVID-19: How Can Bricolage Help? Research in Social Sciences and Technology, 6(2), 22-36. https://doi.org/10.46303/ressat.2021.9

This is an Open Access article distributed under the terms of the Creative Commons Attribution 4.0 International license (https://creativecommons.org/licenses/by/4.0/).
\end{abstract}

\begin{abstract}
This paper discusses using bricolage to mitigate the struggles faced by progressed learners in rural KwaZulu-Natal, South Africa, in the context of the global COVID-19 pandemic. Most progressed learners perform poorly in many subjects, especially sciences. Their struggle has stimulated the need to find ways to enhance their performance. Reinvented artefacts and processes can be used for emancipation, and to transform agendas for improving the performance of progressed learners. To collect data, we used participatory action research, which uses a thematic approach to make meaning of data. We created a WhatsApp group to enable focus group discussions for collecting data, to circumvent COVID-19 restrictions. The group had 14 members, among whom teachers and learners from rural schools. The study found that the factors that contributed to poor performance were a lack of teaching and learning materials, too few teachers, less than optimal teaching methods and learners' attitudes towards science subjects. The main argument of the article is that, in this time characterised by the COVID-19 pandemic, embracing bricolage has the impetus to mitigate challenges relating to the education of progressed learners. Thus, it is important to emancipate teachers, so that they can bricolise the environment for teaching and learning.
\end{abstract}

Keywords: bricolage, progressed learners, participatory action research, teaching approach, academic performance 
Dube, B. \& Ndaba, X.P. Educating Progressed Learners in Times of COVID-19: How Can Bricolage Help?

\section{Introduction}

The COVID-19 pandemic brought uncertainty to many major facets of human life, including education. Numerous measures were put in place by government authorities to limit the spread of the virus in schools, such as a staggered approach to attendance, social distancing, and the use of online teaching and learning (Maphosa \& Dube, 2021). Some researchers, such as McCorkle (2020), describe the COVID-19 as chaotic, and as igniting fear in people and bringing about drastic changes and measures. Many parents and teachers are concerned that these measures could exacerbate progressed learners' poor achievement, as progressed learners perform better with face-to-face instruction, which provides them with more attention from their teachers, who can monitor their academic progress closely. The 2020 National Senior Certificate (NSC) diagnostic report (Department of Basic Education, 2021a), reports a drastic decline in the performance of all South African Grade 12 learners in science subjects. For instance, in life sciences, in $2019,27,7 \%$ of learners failed to achieve $30 \%$ in life sciences, and this number increased to $29 \%$ in 2020; the number failing to achieve $40 \%$ increased from $51 \%$ in 2019 to 52.1\% in 2020. In 2020, learners' performance in life sciences declined sharply: In 2019, 75.5 had achieved at least 30\%, while, in 2020, only $71 \%$ achieved at least $30 \%$. In $2019,51.7 \%$ of learners had succeeded at the $40 \%$ level, while only $42.4 \%$ had achieved $40 \%$ in 2020. The minister of Education, Angie Motshekga, stated that:

The Class of 2020 sat for the National Senior Certificate (NSC) examinations in a year that the world was held to ransom by the Covid-19 pandemic. When this cohort commenced with their exit year of the NSC, no one would have imagined the challenges that they faced (Department of Basic Education, 2021b, p. 1).

Her statement applies, in particular, to progressed learners in rural areas. A study conducted in Namibia found that national Grade 12 academic performance in the Namibian Senior Secondary Certificate declined between 2019 and 2020, by 35\% more in science subjects than in other subjects (Shipepe et al., 2020). Studies have been conducted on the struggles of both teachers and learners during the COVID-19 pandemic. A study conducted by Trust and Whalen (2020) in the United States, on the lack of adequate preparation for online teaching and learning, found that teachers lacked preparation and support in using technology to design quality instruction during the transition to distance learning. These authors report that it was difficult for teachers to find suitable digital tools to support learning and communication with learners during the distance learning period. About $61 \%$ of teachers felt overwhelmed with all the online learning tools and resources available. Another study, by Kaden (2020) in rural Alaska, investigated the wellbeing of students during lockdown. In her findings, Kaden reports that rural students struggled to develop new learning skills during distance learning, and often struggled at home with social isolation and loneliness.

Hyseni Duraku and Hoxha (2020) explain that requests to shift traditional teaching to online formats has increased the levels of stress and anxiety of rural teachers, as they are not used to this method of teaching. Another study, conducted by Dube (2020, p. 4) argues that "it appears that online learning favours urban and well-privileged learners, thus, widening the gap between the poor and the rich, instead of uniting the nation in the fight against COVID-19". A study by Bacher-Hicks et al. (2021) supports Dube's assertion, by reporting that, at the beginning of the 
Dube, B. \& Ndaba, X.P. Educating Progressed Learners in Times of COVID-19: How Can Bricolage Help?

pandemic, the use of Google searches increased at a greater rate in urban schools than in rural schools - this is a clear indication of the effort exerted by parents and learners in wealthier areas to substitute for lost in-person instruction. The implication is that the pandemic and the use of online teaching and learning has led to greater educational inequality.

While the studies quoted above contribute to knowledge of the struggles faced by progressed learners, none have focused on the struggles of rural progressed learners under COVID-19 circumstances in the Uthukela district of KwaZulu-Natal. This study is, thus, unique, because it argues for using locally available knowledge to address the trajectories caused by these struggles. This approach is referred as bricolising the environment (more will be explained as the paper unfolds). Thus, the aim of this paper is to discuss bricolage as an approach to mitigating the struggles faced by rural progressed learners, and to suggest ways bricolage can enhance the performance of progressed learners. The paper is arranged as follows: After a discussion of the theoretical framework, the methodology will be presented, and then the findings and a conclusion.

\section{Theoretical Framing: Bricolage}

We used bricolage as a theoretical framework, as a possible way to enhance performance of progressed learners. Bricolage as a concept was first considered by the French anthropologist Claude Lévi-Strauss in 1967, as a part of his exploration of the nature of sense-making in society (Vanevenhoven et al., 2011, p. 53). It is a theory that uses all available knowledge, whether of immediate interest or outdated, within or outside of people, to solve a given problem (Louridas, 1999). We consider the theory to be relevant, because it advocates that people can construct something out of limited available resources or systems, to achieve new goals (Aagard, 2009, p. 84). In relation to the struggles faced by progressed learners, bricolage is used to refer to the processes by which people acquire objects from across social divisions, to create new cultural identities (Phillimore et al., 2016, p. 8). The bricolage theory allows the combining of resources, and the creation of systems for new purposes, which serve as the mechanism that drives the discovery of innovations in the form of new "services" from existing resources (Duymedjian \& Ruling, 2010, p. 142). In addition to combining resources to address various challenges faced by progressed learners, bricolage facilitates the adaptive design process that is necessary to develop resilience and make solutions to problems more achievable through use of critical resources or social systems (Vanevenhoven et al., 2011, p. 53). In short, bricolage is relevant for this study because it evokes resilience, which emerges from locally available resources, and offers an optimistic outlook (Masten, 2001, p. 228) in the context of COVID-19. The following section will explain the methodology of the paper, which is participatory action research (PAR).

\section{Methodology}

The study is situated within the transformative paradigm; it used a qualitative study design and PAR. PAR is a research approach that evokes the "investigation of actual practices and not abstract practices and learning about the real, material, concrete, and particular practices of particular people in particular places" (Kemmis \& McTaggart, 2007, p. 277). We consider this approach relevant for the study, since its "overriding motivations of activist 'research' are to develop practice aimed at social transformation rather than to use a set of tools aimed at the 'production of knowledge' and the 'solving' of 'local' problems" (Chatterton et al., 2007, p. 220). 
Dube, B. \& Ndaba, X.P. Educating Progressed Learners in Times of COVID-19: How Can Bricolage Help?

"The research methodology identifies the rights of those concerned by the research, and empowering people to set their own schemas for research and development, thereby giving them tenure over the process" (Cornwall \& Jewkes, 1995, p. 1674).

With reference to the struggles faced by progressed learners, PAR "opens doors for the marginalised people [the progressed learners] to criticise, problematize, and claim their condition, which will eventually enable them to overcome" (Glassman \& Erdem, 2014, p. 213). To address the trajectories faced by progressed learners, research should be conducted into "aspects of popular education, community-oriented research, and action for social change to promote marginalized communities, where the quest is to unearth the causes of social inequality and consequently the solution to alleviate the identified problems" (Williams \& Brydon-Miller, 2004, p. 245). In short, PAR as a research approach is an "action and development of knowledge. It has the potential to address research and wider issues of social justice, inclusion and empowerment of minority and often marginalised communities" (Eruera, 2010 , p. 1). In light of the foregoing, PAR enabled us to create a WhatsApp groups with participants affected by poor performance, COVID-19 and the progression policy in rural schools. Assembling such a team is aimed was finding the best solutions emanating from the people experiencing the problem. This approach is important for teasing relevant solutions that address the lived realities of progressed learners and teachers.

To implement PAR and gather data for this research, we created a WhatsApp group to collect qualitative data, as this would help us to circumvent COVID-19 restrictions. The research took place in Uthukela district, 14 participants, both learners and educators, were purposively selected. Eight learners included three boys and four girls aged between 16 and 18, years doing Grades 11 and 12 respectively. There were seven life sciences teachers - four women and three men. The selected participants were considered relevant for the study, since they encountered progression learning every day, as either teachers or learners. Data was gathered over a period of a month through WhatsApp focus discussions, which were necessitated by COVID regulations. In fact, the WhatsApp focus group discussion became the instrument that was used to collect data. The research participants answered two questions: What are the challenges faced by progressed learners in COVID-19 contexts, and How can bricolage mitigate these challenges? The study adhered to ethical principles, such as requiring participants to sign consent forms, indicating that they had the right to withdraw from the research, and using pseudonyms to protect the identities of the participants. The data was analysed through the lens provided by Laws et al. (2003, p. 395), which involves the following steps:

Step 1: Read and reread the collected data.

Step 2: Draw up a preliminary list of themes arising from the data.

Step 3: Reread the data, to check if the themes that had been identified corresponded with what the participants had said, and with the research questions.

Step 4: Link the themes to quotations, scholarly views and notes.

Step 5: Peruse the categories of themes to interpret them. During interpretation of the data, remain cognisant of the research questions.

Step 6: Design a tool to help discern patterns in the data. 
Dube, B. \& Ndaba, X.P. Educating Progressed Learners in Times of COVID-19: How Can Bricolage Help?

Step 7: Interpret the data and derive meaning: This step mainly involves highlighting the research findings and arranging material according to categories that are premised on or guided by the research questions.

The data was returned to the participants for member checking; the participants agreed with the authors that the themes subjected to analysis reflected their ideas on the teaching and learning of progressed learners. The themes that emerged became subheadings in response to the research questions. We considered this as an important step towards ensuring the validity of results. The following section will discuss the findings that responded to the research questions. Pseudonyms are used to protect the identities of the participants.

\section{Results and Discussion}

In the first section, we will present and discuss findings that respond to the first research question, which is, what are the struggles of rural progressed learners and teachers in the context of COVID-19? The data will be arranged according to the themes identified. Participants' responses to this question revealed the background challenges faced by progressed learners in the context of COVID-19. This information exposed the need to bricolise the environment, in order to address the ambivalence of learning.

\section{Shortage of Technological Devices for Online Learning}

The first struggle raised by the participants relates to technological challenges. They indicated that many rural schools lack the financial means to purchase any form of technology, thereby affecting progressed learners. COVID-19 has reminded us that online learning is the way of the future, and its success depends on the availability of technological devices. During the discussion, Msizi, a learner, said:

I have never touched or own any form of technology devices, only my eldest brother has a cell phone at home and he's always away because of signal problem. He has borrowed me to use for these discussions.

Nsika, a teacher, added:

Rural learners may belong to the digital generation, but that doesn't always guarantee them to the full exposure of digital technology and thus make it impossible for learners to participate in online lessons and download course material to help them learn to improve their performances.

Ndleleni, a teacher, indicated that:

The government do not consider us, he acts as if we don't exist. We are not neither against the COVID-19 restrictions and regulations nor online learning but how can we cater for online teaching and learning while our learner doesn't even have textbooks and study guides at our schools.

Considering the points raised by participants, the availability of technological devices is a paramount struggle for rural schools in Uthukela. The findings confirm a challenge facing online teaching and learning during the COVID-19 crisis. For example, a study conducted by Van Lancker and Parolin (2020) reveals that, in rural areas, where electricity is unavailable, teachers 
Dube, B. \& Ndaba, X.P. Educating Progressed Learners in Times of COVID-19: How Can Bricolage Help?

struggle to contact learners, mainly because of the absence of an internet connection, adequate availability of devices, and inability to afford expensive internet data to engage in distance learning. The combination of technological challenges and the lack of electricity in rural areas makes it difficult for progressed learners to improve their academic performance and for teachers to pay attention and attend to these learners' special needs (Parker et al., 2020). Thus, pursuing the transition to the fourth industrial revolution without the basic requirements being in place will leave disadvantaged learners even further behind (Black, 2020). It is the context of the shortage of technological devices, which prevents effective teaching in rural schools, that necessitates the need to think in bricolage terms, as a way to redress the situation and afford progressed learners the opportunity to learn in the context of a crisis, such as presented by the COVID-19 pandemic.

\section{Lack of Parental Involvement}

The next struggle faced by learners is a lack of parental involvement in teaching and learning. The COVID-19 pandemic has reconfigured our way of life, has incapacitated teacher-parent engagement, and forced all participants to adjust to new ways of teaching and learning. The situation is exacerbated by variables such as uncertainty about real online learning, the way learning takes place while students are at home, the role of parents, and whether they are quipped to assist with teaching and learning. Unless these questions they are subjected to various facets of thinking, could result in parents being perceived as incompetent and unwilling to assist in teaching and learning. However, it can be argued that parents are the most valuable resources for mitigating trajectories of learning in the context of COVID-19. Despite the foregoing argument, participants held the view that progressed learners lack support from their parents. During the WhatsApp discussion, Shaka, a learner, indicated that:

During the national lockdown, I have never had an opportunity to do my school work because of the additional household responsibilities, I feel there is no support from my parents.

Mpilo, a learner, added:

My parents lost their jobs because of COVID-19 and national lockdown and since then the home environment is so chaotic and it's directly affecting my learning and because of trying to make ends meet, they fail to assist with school work.

Nkanyezi, a teacher, said:

Many rural progressed learners find attending school to be irrelevant to their lives and as they don't receive enough support from their parents.

The findings speak of a dynamic of ambivalence that progressed learners face in a quest to achieve learning in the time of COVID-19. However, it is also clear that the failure by parents to be involved is not always by design; in some cases, the circumstances facing parents, such as unemployment, stress and health challenges, incapacitate them and prevent them from actively assisting learners. Furthermore, the inability of parents to assist may be exacerbated by ignorance relating to the use of technology. Thus, we concur with the observation by Du Plessis (2014, p. 1115), that: 
Dube, B. \& Ndaba, X.P. Educating Progressed Learners in Times of COVID-19: How Can Bricolage Help?

If parents are not educated themselves, they will have less ability to provide educational support for their children. Homes in rural areas are often ill-equipped to meet the educational needs of children and often lack facilities like electricity. Children have less parental encouragement to go to school. When learners attend school, they find the curriculum less relevant and attractive to their lives, and learners may receive less support for their learning from home.

Parental involvement in education has always been a thorny issue, especially in disadvantaged communities, such as rural areas. Judging from the comments of the participants, it is, furthermore, clear that there is a strong correlation between a learner's performance in the learning process and parental background in terms of social class and ethnicity (Mora \& Escardíbul, 2018). In support of the foregoing, Burgess and Sievertsen (2020) claim that school lockdown is likely to reveal differences in parental involvement and family reactions to the learning opportunities for learners from different types of social background. Findings by Greenlee (2020) reveal that parental education impacts the frequency of children's involvement in academic activities. In essence, participants in this study reported that lack of parental involvement is a trajectory facing rural learners due to a variety of reasons, as stated in this paragraph.

\section{Inequality and Disparity between Schools}

COVID-19 has revealed a divide between rural and town schools. While we are cognisant that the study took place in rural schools, it is important to raise the issue of differential resource allocation for rural and city schools. COVID-19 has shown that governments have not invested enough resources in rural areas, thereby undermining equity and equality of educational provision in post-apartheid South Africa. During the discussion, Phila, a rural learner, said:

During a national lock down, I struggled to keep on track with the curriculum. At school we don't have enough textbooks and study guides, we share everything. My parents can't afford to build a proper house and how can I expect them to buy me textbooks and let alone a cell phone.

Jomo, a teacher, indicated that:

When the Department of Basic Education announced about the online education programmes that will be also taking place on radio stations and television to ensure education continuity, it was like I'm hearing a Greek word that I have never heard before because they know exactly that in rural areas there is poor signal to access radio station and some learners don't have even that radio or television at their homes.

Linda, an urban teacher, said:

Before the lock down instigate, we were called for an urgent workshop where we were trained about the software to use, design of activities that can happen within the digital medium and track our learners' progress during the lock down.

Amahle, an urban learner, said: 
Dube, B. \& Ndaba, X.P. Educating Progressed Learners in Times of COVID-19: How Can Bricolage Help?

At school, I reported that, I usually use my parent's laptop for school work when I'm at home and since they will also be working from home during lock down, I won't be able to use it so, the school gave us tablets to use and we were all trained how to do activities online.

The essence of the participants' views is that there is a gap between urban and rural schools, as urban teachers and learners receive better treatment from the Department of Basic Education than teachers and learners of rural schools do. Because our research took place in a rural context, it is important to raise the issue of resource allocation. We are aware that availability of resources affects the performance of learners. In general, urban schools are equipped with more teaching and learning materials. Some urban teachers have opportunities to undergo training for online teaching, which give these teachers and learners an advantage in executing effective learning in the context of the COVID-19 crisis. This claim resonates with the argument by Du Plessis and Mestry (2019, p. s2) that:

Governments find it more difficult to supply quality education services in rural areas, and various factors weaken the quality of learning and teaching in South Africa's rural areas. Newly trained teachers prefer to teach in urban areas, and as a result rural schools are left with many vacant positions or experience long delays in the filling of vacancies.

This suggestion resonates with Vorster (2020, p. 1), who states that "public schools in poorer areas will continue to struggle to deliver high quality education and will also find social distancing all but impossible, with overcrowded classrooms and too few teachers".

In view of the foregoing, we note that the Department of Basic Education is gambling with the lives of rural teachers, as these teachers are at risk of being infected by COVID-19. Ntaka (2020) argues that:

It is mostly marginalised communities and children who bear the brunt of the effects of school closures as they are the most vulnerable. For a country like South Africa, already battling demons of socio-economic inequality, disruption of the academic calendar has exacerbated the existing disparities in the education system.

In short, the research reveals that rural progressed learners have minimal access to quality learning, as newly trained teachers tend to flock to urban schools to take advantage of opportunities for professional advancement and innovation, and access to facilities.

\section{Enhancing the Academic Performance of Rural Progressed Learners in the Context of COVID-19. How can Bricolage Help?}

The paper does not only highlight the problem, but also presents possible solutions that were discussed by the participants in response to the second research question of the paper, which is, how can the academic performance of rural progressed learners be enhanced in the context of COVID-19? In making suggestions to improve the performance of progressed learners, we show how bricolage thinking can be used as a mitigation strategy. The first point we discuss is using cell phones to address the lack of technological devices. 
Dube, B. \& Ndaba, X.P. Educating Progressed Learners in Times of COVID-19: How Can Bricolage Help?

\section{Bricolise Cell Phones for Teaching and Learning}

While most schools in Uthukela are situated in a rural context, every household has access to cell phones that can be used for teaching and learning. In the discussion, we noted that processes of rural schools acquiring technologies may take a long time to materialise, thus, schools can think of bricolising cell phones. This approach resonates with research done by Maphosa and Dube (2021), who argue that, in the context of deprivation, cell phones can be used to address the challenges caused by the lack of devices. They argue that cell phones can house learning software designed to facilitate teaching and learning. Thus, the participants concurred on the need to share learning software to bridge the problems caused by a lack of smart technological devices - these devices are commonly found in city schools. In a discussion, Thabizolo, a teacher, said:

One of the ways to address lack of technologies is to allow learners to use cell phones in school for teaching and learning. With cell phones, students and teachers can use different soft wares to push the learning agenda.

In support, Thato, a learner added:

Atleast cell-phones are cheap and available at home. It is easy for my mother to find me a cell than a computer.

By enabling people to think and use the available resources to address their lived realities, bricolage makes it possible to use cell phones as one of the ways to bricolage the environment. Cell phones, as technological devices for teaching and learning, can, as suggested by Welland (2018, p. 13) improve the "quality of education, and reductions in truancy and illiteracy". With this in mind, schools should tap into the benefits of using cell phones, and purchase learning programs that can be used by learners and educators to mitigate the absence of face-to-face learning. With the foregoing in mind, we agree with $\operatorname{UNESCO}(2014$, p. 10), that:

ICT [through use of cell phones] can improve student achievement, improve access to schooling, increase efficiencies and reduce costs, enhance students' ability to learn and promote their lifelong learning, and prepare them for a globally competitive workforce.

We conclude this point by arguing that using cell phones and learning software is one of the simplest and cheapest ways to proceed with learning during times of crisis, such as that caused by the COVID-19 pandemic. Through bricolage, the community can be emancipated to think about the resources available to address their trajectories. This does not, however, mean that the Department of Basic Education can ignore the plight of progressed learners. In fact, in the spirit of curricular justice, rural learners matter, and their challenges should be addressed in the same way as those of urban leaners (Dube, 2020). In the following section, we will discuss continuous teacher development as a bricolising strategy to address challenges related to teaching and learning.

\section{Investment in Continuous Professional Development}

COVID-19 has, once again, reminded humanity that learning is a lifelong endeavour, and all available opportunities must be used effectively to gain new knowledge. The pandemic forced 
Dube, B. \& Ndaba, X.P. Educating Progressed Learners in Times of COVID-19: How Can Bricolage Help?

humanity to learn new styles of learning. Despite the call to move into the fourth industrial revolution, many schools continue using traditional forms of learning, due to various challenges, and resistance by some stakeholders. Nevertheless, COVID-19 has forced people to engage with the fourth industrial revolution for teaching and learning. We agree with observation by Williams et al. (2021, p. 4), that "the pandemic also revealed the skills this teacher was missing, some skills he or she did not know he even needed". Thus, online became the only viable and practicable option for learning. Participants reported the need for continuous professional development for teachers, which entails adopting new skills and best practices and bricolising skills and practices to address the challenges caused by the need to engage in online learning. Allen (2009) cited by Srinivasacharlu (2019, p. 30) defines continuous professional development as "the process of tracking and documenting the skills, knowledge, and experience that teachers gain both formally and informally as they work, beyond any initial training. It's a record of what they experience, learn, and then applied". In light of the foregoing, Themba, a rural teacher, indicated that:

During the first hard lockdown, I had lot of time at home, it made me to explore something to keep my mind bust. It is when I discovered various on line webinars that assisted me to know some teaching and learning programs such as Microsoft classroom, blackboard. After being equipped my online teaching improved and was able to share my skills with other colleagues at schools

In this research study, which was informed by bricolage, we consider continuous professional development to be a community asset that could be explored to emancipate educators and enable them to teach in the context of COVID-19. Progressed learners are academically struggling, thus, with educators emancipated with new skills and best practices, teachers can enhance the performance of these learners. We argue, furthermore, that initial teacher education at colleges and universities is no longer sufficient to address the new demands placed on the teaching profession, especially considering ever-changing circumstances that often evoke the need for educators to move to unknown territories in order overcome challenges, such as those experienced in the time of COVID-19. Cognisant of this, we argue that continuous teacher development through online courses, some of them free, can be used as assets to enable educators to confront challenges brought about by COVID-19. In concluding this point, we agree with the observation by Srinivasacharlu (2019, p. 30), that "to prepare efficient future teachers in the 21st century, the teacher educators are required to continually update and equip themselves with ever-increasing skills and competencies to always remain top notch in their profession and do justice to society". Continuous professional development emancipates educators through better training, skills and techniques for improved practice in the classroom (Burgess \& Sievertsen, 2020). In the following section, we will discuss parents as local assets for emancipating progressed learners.

\section{Increasing Parental Engagement}

Parents who are engaged in bricolage thinking are assets that can be used to enhance the teaching and learning of progressed learners. Though parents can be an asset to the school, the issue of ineffective or absent parents who fail to engage in rural progressed learners' learning, was raised as a challenge. The research reveals that there is a need for parents to be 
Dube, B. \& Ndaba, X.P. Educating Progressed Learners in Times of COVID-19: How Can Bricolage Help?

involved in their children's schooling. Parental engagement, as used in this paper, concerns "home-based involvement" in educating learners (Fahey \& Joseph, 2020, p. 6). Parents should "show interest in what they're learning; talking about educational aspirations" (Fahey \& Joseph, 2020 , p. 4). Arguing this way, we are cognisant that some parents may not have knowledge of particular subjects, or understanding of online information, however, this does not undermine the role of parents in enhancing the performance of progressed learners through various ways. In a discussion, Musa, a learner, indicated that:

When schools were closed due to COVID-19 pandemic, my parents were so relieved that I could help them with farming and other household chores.

Sipho, a learner, added that:

I asked my father to help me with my mathematics assignment but he told me that he was not trained to be a teacher. Teachers must do what they are being paid for.

In this line, Thabizolo, a teacher, added:

Apart from the lack of resources in rural schools, learners encounter many challenges also in their homes, we give them homework but it never done, some will tell you that there were no candles to do homework at night. It is also the duty of a parent to assist a learner in the process of learning.

The findings make it clear that involving parents in their children's education is regarded as beneficial for teaching and learning, and for improving the learners' academic performance. This claim is supported by a study by Amani et al. (2020, p. 50), who argue that "the duty of a parent is to make sure that the learner is assisted in the process of learning as much as they possibly can by mentoring, encouraging, leading and inspiring". In this manner, parents become active participants in decision-making about the future of their children. According to the South African Schools Act, 84 of 1996 (Republic of South Africa, 1996), it is a parental responsibility to make the home a suitable environment for learning. This obligation includes ensuring that there is space for the child to study. By doing so, we would have bricolaged parents, and encouraged them to mitigate the poor performance of progressed learners. In short, bricolage can shift people's thinking and enable them to use resources around them or at their disposal effectively.

We agree with Alvi and Gupta (2020:93), who argue that "along with interventions in the education sector, initiatives are also needed to cushion the economic impact on poor families to discourage the use of child labour along with monitoring mechanisms set up to ensure children remain in school". When parents are involved in their children's education, it raises learners' hopes, motivation and self-esteem, and makes them confident about improving their academic performance. By engaging parents in assisting in teaching and learning through various forms, we bricolise education in order to improve the pass rate. In the context of COVID19, the usual ways of enhancing learner performance, such as using resource personnel, is impossible, thus, emancipated parents can help to bridge the gap in the context of crisis. 
Dube, B. \& Ndaba, X.P. Educating Progressed Learners in Times of COVID-19: How Can Bricolage Help?

\section{Conclusion}

The findings of this study helped to answer two questions: What are the challenges faced by progressed learners, and how bricolage can help? The study noted that progressed learners have various challenges such as lack of technological devices, lack of parental support, and suffer from the poor-rich divide, which has been worsened by COVID-19. In light of these challenges, the study noted that bricolage has the impetus to shift people's thinking towards effectively using the resources at their disposal to mitigate challenges associated with online learning. In addition, the study noted that the COVID-19 crisis has forced societies to reconfigure ways to survive the pandemic and ensure that learning continues, despite the challenges at hand. Based on the findings, we make the following recommendations;

- The Department of Basic Education should provide technological devices for teaching and learning. In the meantime, educators and learners can pursue using cell phones as teaching and learning devices. Cell phones are cheaper than laptops, thus, using phones can help to mitigate challenges faced by teaching and learning.

- The Department of Basic Education should provide learning software that can be installed on cell phones to enable learners and educators to explore new online learning approaches, especially in the absence of face-to-face learning.

- We also recommend making continuous professional development opportunities available, to enable educators to acquire new online skills. The Department of Basic Education should provide online training courses for educators, to enable them to face the new challenges associated with teaching under pandemic conditions.

- Finally, parents should be emancipated to assist progressed learners. Parents should play an effective role in helping learners to adjust to new ways of learning, giving their children time to learn at home and collaborating with educators to develop strategies to ensure teaching and learning is not disrupted in the context of COVID-19.

\section{References}

Aagard, M. (2009). Bricolage: Making do with what is at hand. Creative Nursing, 15(2), 82-84. https://doi.org/ 10.1891/1078-4535.15.2.82

Alvi, M., \& Gupta, M. (2020). Learning in times of lockdown: how Covid-19 is affecting education and food security in India. Food Security, 12(4), 793-796. https://doi.org/10.1007/s12571-020-01065-4

Amani, M., Nazifi, M., \& Sorkhabi, N. (2020). Parenting styles and academic achievement of early adolescent girls in Iran: Mediating roles of parent involvement and self-regulated learning. European Journal of Psychology of Education, 35(1), 49-72. https://doi.org/10.1007/s10212-019-00422-y

Bacher-Hicks, A., Goodman, J., \& Mulhern, C. (2021). Inequality in household adaptation to schooling shocks: COVID-induced online learning engagement in real time. Journal of Public Economics, 193(January), 104345. https://doi.org/10.1016/j.jpubeco.2020.104345

Black, S. (2020, May 11). The problem with Stephen Grootes' views about online learning [Opinion]. Daily Maverick. Retrieved from 
Dube, B. \& Ndaba, X.P. Educating Progressed Learners in Times of COVID-19: How Can Bricolage Help?

https://www.dailymaverick.co.za/opinionista/2020-05-11-the-problem-with-stephengrootes-views-about-online-learning/

Burgess, S., \& Sievertsen, H. H. (2020, April 1). Schools, skills, and learning: The impact of COVID-19 on education. Vox EU, CEPR Policy Portal. Retrieved from https://voxeu.org/article/impact-covid-19-education.

Chatterton, P., Fuller, D., \& Routledge, P. (2007). Relating action to activism. Theoretical and methodological reflections. In S. Kindon, R. Pain, \& Kesby, M. (Eds.), Participatory action research approaches and methods: connecting people, participation and place (pp. 219-222). Routledge.

Cornwall, A., \& Jewkes, R. (1995). What is participatory action research? Social Science \& Medicine, 41(12), 1666-1676. https://doi.org/10.1016/0277-9536(95)00127-S

Department of Basic Education. (2021a). National Senior Certificate Examinations 2020. Diagnostic report. Part 1: Content subjects. Pretoria: Department of Basic Education. Retrieved from https://www.education.gov.za/Resources/Reports.aspx

Department of Basic Education (2021b). National Senior Certificate Examinations 2020. Diagnostic report. Part 3: Technology subjects. Pretoria: Department of Basic Education. Retrieved from https://www.education.gov.za/Portals/0/Documents/Reports/2021\%20NSC\%20Repor ts/Diagnostic\%20Report\%202020\%20-\%20Part\%203. pdf?ver=2021-03-25-103642-000

Dube, B. (2020). Rural online learning in the context of COVID 19 in South Africa: Evoking an inclusive education approach. Multidisciplinary Journal of Educational Research, 10(2), 135-157.

Du Plessis, P., (2014). Problems and complexities in rural schools: Challenges of education and social development. Mediterranean Journal of Social Sciences, 5(20), 1109. https://doi.org/ 10.5901/mjss.2014.v5n20p1109

Du Plessis, P., \& Mestry, R., (2019). Teachers for rural schools-a challenge for South Africa. South African Journal of Education, 39(Suppl. 1). https://doi.org/10.15700/saje.v39ns1a1774

Duymedjian, R., \& Rüling, C.C. (2010). Towards a foundation of bricolage in organization and management theory. Organization Studies, 31(2), 133-151. https://doi.org/10.1177/0170840609347051

Eruera, M. (2010). Ma Te Whānau Te Huarahi Motuhake: Whānau participatory action research groups. MAI Review 3(2010), 1-9.

Fahey, G., \& Joseph, B. (2020). Parents' perspectives on home-based learning in the COVID-19 pandemic. CIS Analysis Paper No. 15. Centre for Independent Studies. Retrieved from https://www.cis.org.au/app/uploads/2020/09/ap15.pdf

Glassman, M., \& Erdem, G. (2014). Participatory action research and its meaning. Vivencia, praxis and conscientisation. Adult Education Quarterly, 64(3), 206-221. https://doi.org/10.1177/0741713614523667

Greenlee, E. (2020, July 16). Parents supporting learning at home during the COVID-19 pandemic. Statistics Canada. Retrieved from https://www150.statcan.gc.ca/n1/pub/45-28-0001/2020001/article/00040-eng.htm

Hyseni Duraku, Z., \& Hoxha, N. (2020, September). The impact of COVID-19, school closure, and social isolation on gifted students' wellbeing and attitudes toward remote (online) 
Dube, B. \& Ndaba, X.P. Educating Progressed Learners in Times of COVID-19: How Can Bricolage Help?

learning. Retrieved from

https://www.researchgate.net/publication/344098512_The_impact_of_COVID19_school_closure_and_social_isolation_on_gifted_students'_wellbeing_and_attitud es_toward_remote_online_learning

Kaden, U. 2020. COVID-19 school closure-related changes to the professional life of a K-12 teacher. Education Sciences, 10(6), 165.

Kemmis, S., \& McTaggart, R. (2007). Communicative action and public sphere. In N. K. Denzin, \& Y. Lincoln (Eds.), The SAGE handbook of qualitative research (pp. 559-603). Sage.

Laws, S., Harper, C., \& Marcus, R. (2003). Research for development. Sage.

Louridas, P. (1999). Design as bricolage: Anthropology meets design thinking. Design Studies, 20(6), 517-535.

Maphosa, V., \& Dube, B. (2021). Local language numeracy kindergarten prototype design to support home-based learning during and post COVID-19 pandemic. Contemporary Educational Technology, 13(3), ep301. https://doi.org/10.30935/cedtech/10846

Masten, A. S. (2001). Ordinary magic. Resilience processes in development. American Psychologist, 53(3), 227-238. https://doi.org/10.1037/0003-066X.56.3.227

McCorkle, W. (2020). Problematizing immigration restrictions during COVID-19 in the social studies classroom. Research in Social Sciences and Technology, 5(3), 1-24. https://doi.org/10.46303/ressat.05.03.1

Mora, T., \& Escardíbul, J. O. (2018). Home environment and parental involvement in homework during adolescence in Catalonia (Spain). Youth and Society, 50(2), 183-203. https://doi.org/10.1177/0044118X15626050

Ntaka, N. (2020, June 5). Basic education in a pandemic: The pitfalls of online learning in an already unequal society [Opinion]. Daily Maverick. Retrieved from https://www.dailymaverick.co.za/opinionista/2020-06-05-basic-education-in apandemic-the-pitfalls-of-online-learning-in-an-alreadyunequal-society/

Parker, R., Morris, K., \& Hofmeyr, J. (2020). Education, inequality and innovation in the time of COVID-19. Jet Education.

Phillimore, J. I., Humphries, R., Klaas, F., \& Knecht, M. (2016). Bricolage: Potential as a conceptual tool for understanding access to welfare in superdiverse neighbourhoods. IRIS Working Paper Series, No. 14/2016. Institute for Research into Superdiversity, University of Birmingham.

Republic of South Africa. (1996). South African Schools Act 84 of 1996. Government Gazette, Vol. 377, No. 17579. Retrieved from https://www.gov.za/sites/default/files/gcis_document/201409/act84of1996.pdf

Shipepe, A., Jormanainen, I., \& Sutinen, E. (2020, October). Educational robotics initiatives in Namibia and worldwide. Proceedings of the Eighth International Conference on Technological Ecosystems for Enhancing Multiculturality (pp. 48-53). https://doi.org/10.1145/3434780.3436675.

Srinivasacharlu, A. (2019) Continuing professional development (CPD) of teacher educators in 21st century. Shanlax International Journal of Education, 7(4), 29-33. https://doi.org/10.34293/education.v7i4.624 
Dube, B. \& Ndaba, X.P. Educating Progressed Learners in Times of COVID-19: How Can Bricolage Help?

Trust, T., \& Whalen, J. 2020. Should teachers be trained in emergency remote teaching? Lessons learned from the COVID-19 pandemic. Journal of Technology and Teacher Education, 28(2), 189-199.

UNESCO (2014). Information and communication technology (ICT) in education in Asia: A comparative analysis of ICT integration and e-readiness in schools across Asia. Information Paper No. 22. UNESCO Institute for Statistics. Retrieved from http://www.uis.unesco.org/Communication/Documents/ICT-asia-en.pdf

Van Lancker, W., \& Parolin, Z. (2020). COVID-19, school closures, and child poverty: a social crisis in the making. The Lancet Public Health, 5(5), e243-e244. https://doi.org/10.1016/S2468-2667(20)30084-0

Vanevenhoven, J., Winkel, D., Malewicki, D., Dougan, W. L., \& Bronson, J. (2011). Varieties of bricolage and the process of entrepreneurship. New England Journal of Entrepreneurship 14(2), 53-66.

Vorster R. (2020, May 5) the challenges of hunger and education for South Africa's children (Part One) [Opinion]. Daily Maverick. Retrieved from https://www.dailymaverick. co.za/opinionista/2020-05-05-part-one-the-challenges-ofhunger-and-education

Welland, A. (2018, April). Education and the electrification of rural schools. DBE Guidelines on how parents can support children at school. Technical Report 13. Smart Villages. Retrieved from https://e4sv.org/wp-content/uploads/2017/05/TR13-Education-andthe-Electrification-of-Rural-Schools_web-1.pdf

Williams, B. T., \& Brydon-Miller, M. (2004). Changing directions: Participatory action research, agency, and representation. In S. G. Brown, \& S. I. Dobrin (Eds.), Ethnography unbound: From theory shock to critical praxis (pp. 241-257). State University of New York Press.

Williams, T. K., Mclntosh, R.W., \& Russell, W. B. (2021). Equity in distance education during COVID-19. Research in Social Sciences and Technology, 6(1), 1-24. https://doi.org/10.46303/ressat.2021.1 